\title{
Rereading the Decline of the Illustrated Song: Three Crisis Discourses in Moving Picture World, 1908
}

\begin{abstract}
Historians have well documented the decline of illustrated songs in nickelodeons in the United States from 1909 to 1913. In this article, a close examination of the 1907 and 1908 issues of Moving Picture World shows that several crises occurred before 1909 that help us understand this decline. Here I examine three main crises: the structural crisis of free music, the economic and aesthetic crisis of piracy, and the legal dispute over exclusive illustration rights.
\end{abstract}

KEYWORDS: illustrated song, lantern slides, lantern industry, magic lantern, Moving Picture World, music industry, piracy

"The illustrated song is as important to the five-cent theater as the moving picture."

\section{-Alfred L. Simpson, manufacturer AND SELLER OF SLIDES, JANUARY 11, 1908}

The point of departure for the present research was my astonishment at illustrated-song practices in North America. Songs illustrated by a series of glass slides projected with a magic lantern shared some portion of nickelodeon programming with kinematograph films. I was drawn in particular to the issues raised when one confronts (after the fact) historiographical discourses with (contemporary) professional discourses around the practice. On the one hand, the date 1909 appears to be accepted as a turning point in the history of this practice. Jennifer Wild, drawing on the work of Rick Altman, chose the period 1909 to 1913 to study the decline of the illustrated song. ${ }^{1}$ Richard Abel also explicitly chose this date: "let me touch on one last moment in 1909, when Moving Picture World and the New York Dramatic Mirror already were claiming that illustrated songs were 'degraded' and their popularity was on the wane." ${ }^{2}$ Note 
that Abel bases his dating of the decline of illustrated songs on statements in the trade press, and in particular on Moving Picture World. My own study of the trade journal Moving Picture World for 1907 and 1908, which was facilitated by its complete digitizing, ${ }^{3}$ reveals that the illustrated-song industry was already experiencing difficulties before 1909.

Let us be clear. Establishing 1909 as a key date was not that categorical, and this dating has already been placed in context by Abel himself. Following the remark quoted above, he indicates that this date is valid for New York in particular and even for Chicago. Here is where Moving Picture World's readership pool was located, thereby accounting for the choice of date. Abel sees this decline later for the states of Washington, Michigan, and Ohio, for example. Similarly, Jennifer Wild chose 1909 not as the decisive point in the decline of illustrated songs but rather as the beginning of a gradual period of decline over several years. Nevertheless, we must necessarily discuss the accuracy of this date as the beginning of the process as well. Although the period from 1909 to 1913 saw the collapse of the illustrated song, the trade press was reporting on its troubles as early as 1907. With hindsight, these earlier troubles can be read as foretelling an imminent decline, even though this appears to be difficult to demonstrate without engaging in teleology. Whatever the case, it is worthwhile to document these internal debates and problems from the perspective of the process of institutionalization to which a publication such as Moving Picture World was contributing and which led both to the decline of the illustrated song and to the hegemony of moving pictures. The 1910s indeed witnessed a paradigm shift in the making of cinematographic views. For instance, there was a change from cinématographe as one of many attractions (e.g., the illustrated song) to a coded narrative cinema, which André Gaudreault termed "cinématographieattraction" and "institutional cinema." ${ }^{4}$

I will focus on crisis discourses surrounding the illustrated song in Moving Picture World in 1907 and 1908-the first three volumes of this weekly journal, as published by J. P. Chalmers, who cofounded it in March 1907 with Alfred H. Saunders. ${ }^{5}$ While the magazine discussed the crises at greater length in 1908 , we can conclude from the outset that the problems encountered by the illustrated-song industry were less severe in 1907 than they became by 1908. It may also be that the publishers founded the journal at a time of industrial growth, in particular the growth of illustrated songs, but that in the face of the difficulties with which this industry was confronted their editorial line altered to suit the conditions. Because this study addresses industrial questions through the prism of a journal, it is appropriate to pay express attention to discourses where editorial and symbolic issues are often implicit. In other words, the articles in Moving Picture World have a dual status: they are both objective and speculative, both 
factual documents and biased discourses. They are written by agents who often have a direct stake in the industry issues they discuss. As quoted in the epigraph by Alfred L. Simpson, a manufacturer and seller of slides, "The illustrated song is as important to the five-cent theater as the moving picture." Simpson conveys both the desire for cultural and commercial hegemony and the sense that the illustrated song is running out of steam.

Three moments of crisis will be analyzed. The first crisis was structural, set in motion by the music publishers who stopped producing and distributing illustrated-song slides at their own expense. The second was economic and aesthetic: the pirating of slides. The third concerns exclusivity contracts for song illustrations. This essay critically examines these discourses by relating the historical facts presented in Moving Picture World to the journal's position in the industry. These three crises are strongly intertwined, but by discussing them separately, I can better describe the interconnected relations. The three crises are often mentioned in the same articles; moreover, they generally worsen in tandem, which would tend to confirm the hypothesis that the sector began to weaken from 1908 onward.

\section{A STRUCTURAL CRISIS: THE ROLE OF MUSIC PUBLISHERS}

The structural crisis was particularly well documented by Moving Picture World between April and June 1908. At the time, the music industry was operating under the sheet-music model, which was thrown into upheaval by sound recording technology. Richard Abel and Rick Altman underscore the interdependence of the actors in the music industry during this period. Abel emphasizes the central role of music publishers: "Specifically, the illustrated song depended on an already centralized industry of production: New York's Tin Pan Alley of music publishers and New York or Chicago song slide manufacturers" (emphasis added). ${ }^{7}$ Altman remarks that this industrial organization is perceptible in the slides themselves: "The tight connections between song slide makers, sheet music publishers, and performers (called 'song illustrators') were clearly evident in the slides used as titles, which were typically based on the cover of the sheet music for the song in question, often supplemented by a picture of a song slide or a successful song illustrator."

To complete this picture, we must demonstrate that this industrial organization had five sectors and not just three. In this respect, the opening paragraph of an opinion column entitled "Music Publishers as Distributers [sic] of Lantern Slides," signed by Dan'l H. Palmer, is enlightening:

The music publishers of New York and other cities of America one year ago had the practical monopoly of dealing in song slides. They 
were the distributers [sic], and people wanting song slides were instructed at the various manufacturing centers of the commodity to go to the music publishers for their slides. The manufacturers of slides were, with a few inconsequential exceptions, tied to the music publishers, and could get no work unless it came from the music publishers.... At that time the publishers were vieing [sic] with each other in furnishing free talent to theaters, nickelodeons and other places where songs could be presented to the public. ${ }^{9}$ (emphasis added)

The music publishers (sector 1) appear to have dominated, or even to have enjoyed a "practical monopoly." They commissioned "manufacturers" or "slide makers" (sector 2) to illustrate their songs and distributed (sector 3 ) the slides themselves to venues (sector 4) or even directly to singers (sector 5). ${ }^{10}$ To this must be added a number of other distributors, variously known in Moving Picture World in 1907 and 1908 as "slide bureaus," "slide renters," "film exchanges" and "dealers," who were independent of the music publishers but often tied to the slide manufacturers. This distinction was formalized in 1907 in the fourth issue of the journal, in which the professional directory published in its pages under the title Buyers' Guide was augmented with a rubric headed Music Publishers Who Issue Song Slides. ${ }^{11}$ This rounded out the section Song Slides for Illustrated Songs (manufacturers/distributors), which was present from the first issue of the weekly paper. The music publishers, then in a dominant economic position, had series of slides produced at their expense which they often distributed free of charge to exhibitors and/or singers. Illustrated songs were the means of advertising the songs, whose scores were sold directly from nickelodeon ticket counters. ${ }^{12}$ Technological change, however, gradually altered the situation in favor of recorded music: as Rick Altman points out, "Money once spent on pianos and sheet music would henceforth be spent on phonographs and records. By 1909, with annual sales of twenty-seven million records worth $\$ 12$ million, the phonograph business had rocketed to more than double sheet music's \$5.5 million sales." ${ }^{13}$ In April 1908, music publishers abandoned the free distribution of song slides, throwing the entire illustrated-song ecosystem into upheaval.

The arrival of the phonograph alone does not account for this change in the model. We must also consider the explosion in the number of nickelodeons, most of which showed illustrated-song slides. ${ }^{14}$ The corollary of this explosion was a drop in the quality of the show, with respect in particular to the talent of the singers ("song illustrators" or "illustrated singers"), who had to be recruited on a large scale to provide for the new venues. Everything thus suggests that 
the music publishers, feeling the strongest financial effect of these combined factors, decided to stop distributing free slides. As Matthew Mooney remarks in his dissertation on sheet music, "some sources indicate that this transition was initiated by the music publishers themselves, who balked at supplying a growing army of generally less-talented picture-show song illustrators with expensive slide sets that these singers were ill-disposed to purchase" (emphasis added). ${ }^{15}$ The difficulty of the prevailing logic is understandable: music publishers had to manufacture the slides at their own expense to supply a growing number of venues at the same time as the songs were much less well performed by singers of little talent.

On April 25, 1908, Moving Picture World published an article entitled "The Free Music Graft Is Ended," which stated: "The music publishers of New York and other cities got together a few days ago and decided to shut out the lantern slide renters, film exchanges and dealers in slides from any more free music." ${ }^{16}$ Mooney, emphasizing the repeated use of the term insolent, highlights the music publishers' exasperation with exhibitors' pressing and deliberately discourteous demands that they be supplied with large quantities of series of slides free of charge. The journal was willing to echo the music publishers' concerns. The same April 25 article, for instance, quotes a large publisher who said, "We have had as high as two hundred letters in our mail in one morning from rental bureaus all over the United States asking [for] from twelve to twenty professional copies of music. Most of the letters were discourteous in tone and many of them were actually insolent. So we got together and decided to let our friends who are running rental bureaus buy their music." 17

On May 2, the journal published an anonymous letter (signed "a sympathiser" [sic]): "Many slide and film exchanges throughout the country are loath to believe that the music publishers of New York dare to cut them off from the graft of free music which they have enjoyed so long without let or hindrance, until some of them have become so arrogant that their requests for favors have become insolent." ${ }^{18}$ But this finding must be qualified. By highlighting a moral issue-the deterioration in the relations among publishers, distributors, and exhibitors-the journal minimized the financial question, which nevertheless comes through in the discourse. The journal's editorial goal appears to have been to consolidate, and if possible to join together, so-called legitimate manufacturers and exhibitors (see above), whose respectable practices and quality products were necessarily more costly. For them, this change of model was a necessity, something explicitly formulated in the letter of May 2: "The profit on any set of lantern slides that is fit to be thrown on the screen at $\$ 5.00$ per set of eighteen slides is so small that the slide makers, if they furnish free music to 
the rental bureaus[,] will see their profits wiped out altogether, and will have to quit business." 19 The following week, after the argument had reached its peak, an editorial in the paper stated that "The music publisher is primarily to blame for the condition of the slide business. He argued that because he had to give his slides out to the singers free the slide maker ought to lower his price. This was false business ethics, but the slide makers did shave their prices when they found their business was going to cut-throat competitors, who while they never did good work, are getting the work." 20

The free model thus pushed the music publishers to turn to less-costly manufacturers to reduce their production costs. But this solution was not sustainable because these slides, deemed to be of poor quality, had a negative effect on the promotion of illustrated songs. The legitimate manufacturers thus sought to recover the market.

As mentioned above, Moving Picture World reported an overall decline in the talent of the song illustrators. This too needs to be put in perspective. On the one hand, Altman shows that, on the contrary, some singers were recognized for their talent. ${ }^{21}$ On the other hand, by publishing a letter from a singer in its Correspondence section, the journal demonstrated that there were two categories of singers. In this sense, the signature used by this anonymous author is clear: "A singer who pays for his slides" (emphasis added). ${ }^{22}$ This firsthand commentary illuminates the practices that were crushing the music publishers. First of all, it recounts that an illegal and unofficial blacklist was circulating among the publishers to identify those singers who kept the slides that were lent to them. The singers were thus accused of dishonesty, but the argument was easily countered: "The simple fact that many publishers have been in the habit of leaving slides with a note to the singer in their dressing room at theaters is alone enough to condemn this list." ${ }^{23}$ The publishers' bad faith was thus exposed: nothing obliged them to provide the slides free of charge, and nothing obliged the "illustrator" (the singer) to return them. In a similar vein, some singers lent or sold these slides after they used them and were broadly accused of dealing in stolen goods ("The publishers complain that the singers sell the slides to dealers in lantern slides"24), but here too nothing obliged the publishers to give them the slides in the first place.

The singers' position was ambiguous but supported on the whole by Moving Picture World. The accusatory letter against the music publishers not only set out mostly persuasive arguments but also established a dichotomy within the singing profession: between good practices (renting one's slides) and bad practices, such as fencing the slides. The latter was condemned but almost excused because the disorder caused by the music publishers had made singers' lives precarious. This distinction between good and bad practices, applied to 
singers but also to slide manufacturers and distributors, was central to Moving Picture World's discourse.

In late June and early July 1908 , two more articles addressed this crisis in response to the dispute. Focused on the success of songs, they mention that no song had recently attained the status of a popular hit. The structural disorder had weakened the promotion of songs, which was a bad outcome for every part of the industry.

The first of these two articles was a short item published under the rubric Among the Slide Makers on June 20: "A subscriber wants to know what is the latest and best song hit in New York. Will some music publisher kindly inform us and send us a copy of the song? We don't know of any hits this year."25 The item's brevity makes it hard to interpret. The question highlighted above reads differently depending on whether we view it as ironic or legitimately concerned, each of which seems plausible. Speaking directly to the music publishers may seem sly, as they were cast as having thrown the market into disorder and at the same time as being the victims of this disorder. Between the lines, however, we understand that the songs' success affected the manufacturers, the singers, and the owners of the venues alike, and so this question must also be understood literally.

The second article highlights this complexity and responds to the query set out in the first. It was longer and once again took the form of an anonymous letter, entitled "Not a Hit Song on the Market" and signed "A Music Publisher." The article was thus a defense, as it was the music publishers who were the main accused party. The letter sought in a sense to spread the blame among every sector of the industry. Here too the target was clearly defined: "Music publishers in this country are just waking up to the fact that the popular song is in a state of extreme sickness ... The cause is the moving picture theatre." ${ }^{26}$ The author points to rivalry among the many nickelodeons. Caught up in a competition for novelty and seeking to change their programs with unbridled frequency, the owners did not allow time for the songs to take hold: "This is happening to every song of the present day. They are not run long enough to let the public become acquainted with them and they die." ${ }^{27}$ Here too this letter offers a highly ambivalent discourse: it certainly made it possible to downplay somewhat the role of the music publishers, but it arrived late in the discussion, commenting on it more than contributing to it. In addition, it reinforced the contrast between legitimate exhibitors and others, and in this sense advanced the journal's editorial line: "There isn't a hit on the market, and there won't be until the hundreds of vaudeville theatres now running pictures return to their legitimate field" (emphasis added). ${ }^{28}$

Between April and June 1908, the illustrated-song market was thrown into disorder following the music publishers' decision to put a stop to the 
system of supplying slides free of charge. Moving Picture World developed an accusatory discourse toward these publishers, thereby revealing its editorial stance on the side of the manufacturers and distributors of so-called legitimate slides. Between the lines, we must read this disturbance as temporarily masking another. By accusing the music publishers of causing disorder, the lantern operators avoided an even older crisis, one they were reluctant to stem: the pirating of slides.

\section{AN ECONOMIC AND AESTHETIC CRISIS WITH SYMBOLIC IMPORT: PIRACY}

An exploration of the trade press in the nickelodeon era reveals that the use of the term pirate is not new in media discourse. The semantic field of piracy was deliberately employed in many ways in the early twentieth century: the theft, reselling, and copying of both slides and films were major issues of the day, as was the establishment of a legal framework to protect intellectual property. These questions run through Moving Picture World's earliest years.

Jennifer Wild points out an astonishing paradox, which she argues contributed to the decline of the illustrated song: "It thus appears that this period saw all the processes associated with the slides, from production to projection, as an industry closely connected with if not simply open to the amateur enthusiast or the small artisanal producer, who was often the owner of a nickelodeon." ${ }^{29}$ Wild even remarks on the "'anti-amateur' discourse of the trade press." The polysemous nature of the term amateur should not mislead us: the journal really did encourage everyone to dabble in lantern slides and moving pictures as a pastime. Nevertheless, in Moving Picture World's view, only properly trained professionals should venture into the industry if there were not to be grave structural disturbances.

Right from the first issue of 1908, a polarized discourse put the slide manufacturers into two camps, based on the criterion of good practices. In "Slide Makers Organizing," the editor presents arguments from manufacturer Alfred Simpson that advance a rhetoric of contrast to posit two clashing symbolic entities. The first paragraph of the article thus remarked that "the makers of colored lantern slides for illustrated songs have started a movement to band themselves together for mutual protection against pirates" (manufacturers vs. pirates). This is also plainly apparent in Simpson's speech: "Pirates are rapidly taking our profits away in spite of our every effort to defeat them"; "No wonder they undersell us" (pirates vs. us). ${ }^{30}$ Likewise, an article from July 4, 1908, described DeWitt C. Wheeler, a New York manufacturer, as a well-informed amateur who conscientiously became professional: "An amateur photographer by choice, Mr. Wheeler accidentally drifted into the song slide business in its infancy and has built up 
what is perhaps the largest business of this kind in existence." This laudatory portrait made it possible to better contrast him with slide copiers: "What can be more discouraging to such a concern, or to any one [sic] who is working on the same lines, than to have a set of their slides copied by one of the pirate sharks that abound?"31 This was not innocuous; the two articles quoted here report a desire to organize: Simpson wanted to set up a guild ("Organization of the slide makers for self-preservation has become a necessity"), and Wheeler favored founding a "Slide Makers' Protective Association": "Our object in calling upon Mr. Wheeler was to discuss the proposed Slide Makers' Protective Association, and he was heartily in accord with the idea. The most wide reaching benefit of such an organization would be to rid the trade of the junk of the copyist." ${ }^{22}$

While the strategy dominating these discourses was the construction of an ethical clash between two symbolic entities, other strategies were also at work, particularly the use of other semantic fields. This is astonishing in an article from June 13, 1908, concerning the copying of a series of sacred songs. The article took the resolutely habitual form of an anonymous letter, signed "Operator": ${ }^{33}$ "There is one evil that the public are beginning to resent in moving picture shows, and that is the use of the trash that results from copying colored lantern slides. The chief offender in this line is a Chicago concern, and their chief sin is the copying and putting on the market of slides for sacred songs, which the managers of theaters ... allow themselves to be victimized." ${ }^{34}$ This paragraph intensifies in an interesting manner the condemnation of pirates, now flatly accused of sinning. Because it was a question of denouncing both their illegality and their immorality, the law and religion were interpolated in an unforgiving sentence, almost a sermon: "Every person who issues or uses copied slides will be exposed and held up to the vengeance of a defrauded public. The man who copies another maker's work is a fraud, and if he sells such work to people as originals he's a swindler and deserves to be punished." ${ }^{35}$ This rhetoric appears to have been motivated by the religious topics of the songs concerned, but it was also used in other cases. As an example, a brief news item with an eschatological flavor on July 4, 1908, remarked that "knowingly [buying copies] makes the buyer a party to the crime-for it is a crime, and punishment will come." ${ }^{36}$ Other techniques also recur: a semantics of illness ("injuring") and of amateurism ("daubers," "bathroom photographers," "slides painted like a house painter does his work"), or simply insults ("punk," "junk," “trash," etc.). ${ }^{37}$

Practices of piracy fell into two categories: theft and copying. I have already mentioned the practice by song illustrators of stealing slides. Because publishers gave most slides to singers, the singers could easily cash in their collections or even set up a parallel business of cheap copies. Although the problem was part of the heart of the debate over free slides, it persisted throughout 
the year 1908. It was, for example, the subject of a long article on October 30 in the section Among the Slide Makers: "Complaints are being made by the film and slide rental bureaus in Eastern and Central New York State that a singer employed in an Albany theater is conducting a slide rental bureau on slides borrowed from the music publishers." ${ }^{38}$ The problem was a thorny one, however, because of the hazy legal framework: "It has been shown that the pernicious practice of loaning slides free to a singer has been his fall, as while a singer cannot be legally held for selling a loaned set of slides, morally the act is theft as much as if the slides were stolen." ${ }^{39}$ Being unable to advance the legal argument, but compelled to protect their industry, the journal again used a moral tone with shades of religion ("his fall"): even if it is not theft in the eyes of the law, on a moral level it is.

The second piracy complaint concerned the making of slides. One criterion was employed to distinguish among slide makers: so-called legitimate manufacturers were those who carried out their own "posing," meaning that they themselves took the photographs illustrating the songs. ${ }^{40}$ All the others were pirates who copied or faked-often very poorly-these original slides: "In New York there are about half a dozen slide-makers who do original work. They have their own photographers, who pose their own groups, take their own original negatives and create color schemes. Against this there are a dozen manufacturers who never see an original negative, and wouldn't know what to do with it if they did." ${ }^{41}$ These comments by Alfred Simpson put the blame on New York, but it appears that Chicago was not spared: "Rumors are abroad again that a prominent slide concern in Chicago are inveterate copyists of other people's slides. We have run down this rumor and found it to be a fact." ${ }^{42}$ The rise in piracy was bad for legitimate manufacturers financially because copied slides were unfair competition. Taking photographs was a financial investment, especially if it involved outdoor locations and extras. Simpson gives an example with detailed figures: "I was commissioned to illustrate an Indian song. I secured the services of the Indians in the Hippodrome show, together with an interpreter, and took them out of town for a day, hiring a camp outfit and feeding all these people as well as paying railroad fares. The initial cost of those two dozen or so negatives amounted to $\$ 500$ or more." ${ }^{43}$ These slides were sold for five dollars, but pirates quickly made a copy of the series, selling it for only four dollars. Under these conditions, it would appear that legitimate manufacturers had difficulty recovering their onerous investments. They were thus tempted to lower their production costs, and this is what Simpson did. But this solution was not satisfactory: "Immediately [Simpson] was swamped with work and other makers had to meet his price to keep their trade until the price finally settled to $\$ 5$ a set, leaving a very small margin of profit for good work. The sufferers 
have to a great extent in this business been the girls who color, as the price for labor has steadily declined as the music publishers howled for cheaper slides." ${ }^{44}$ Colorists forced to work more quickly did mediocre work. Lowering costs was thus abandoned in favor of promoting the technical quality of legitimate slides.

Here there arises the idea that while the manufacturers ran a direct financial risk, they also faced symbolic issues whose financial consequences could be even more lasting. In terms of the technical and aesthetic quality of the performances, the rise in pirated slides pulled the industry downward. On this point, Moving Picture World's position was unequivocal: audiences were aware of the poor quality of certain programs, with the risk that they would abandon the nickelodeons. The reception of pirated slides was widely discussed in the columns of the paper, under very assertive headings: "They think the public is not wise to their faking! They mistake themselves." ${ }^{45}$ In a rare move, on August 15,1908 , the journal's editors added a critical appendix to the end of a letter published in the Correspondence section in order to emphasize this point: "[The above is a copy of a letter received from a prominent Chicago lantern slide manufacturer by another slide maker in New York City. The writer is wrong in the belief that the public are not willing to pay for the best slides. They are getting wise to the work of the copyist and good work is always in demand.-Ed.]"46 The journal appears to be clearly asserting the public's lucidity. This, however, was not without contradiction, in the first place with a recurring argument that served to blame bad venue owners: "the managers of theaters, ignorant alike of what constitutes good or bad work, and not knowing an original from a copied slide." ${ }^{47}$ There is an obvious contradiction between assertions that audiences were capable of detecting copied slides on the one hand and on the other that the worst venue owners, for their part, were not capable of this. Only by examining the publication extensively for the entire year can we conclude that this is not a glaring contradiction. These two sides of the discourse served two complementary purposes: to attack the poor practices of certain owners and to promote the good practices of the rest. These good practices would make it possible to bring together a public of connoisseurs around performances already spoken of by the journal as forms of art ("the art of slide making"; "photographic slide making is an $\operatorname{art}^{\mathrm{M}}{ }^{48}$ ).

Moving Picture World identified and described piracy practices but also spoke of ways to protect oneself from them or even to stem the practice. The first solution, a radical one, was denunciation. The pirate's name should circulate so that their slides would not be purchased. Moving Picture World did not, properly speaking, denounce specific pirates and did not keep a blacklist: that would be illegal. ${ }^{49}$ When the journal targeted an individual or a company, it did so under the cover of circumlocution: "A certain large theater in this city 
which has been refused any more free lantern slides by the music publishers is faking up sets of slides for songs from old slides" (emphasis added); ${ }^{50}$ "rumors are abroad again that a prominent slide concern in Chicago are inveterate copyists of other people's slides." ${ }^{11}$ Nevertheless, on July 11 the paper published an explicit denunciation: “The Francis Day \& Hunter Music Publishing Company, under date of July 2 , have been circulating a letter over their signature, among the other music publishers and slide dealers, calling attention to the operations of one Frank McCready, in Song slides." 52 The newspaper skillfully shifted the denunciation to the music publisher: read literally, the paper merely reported their action in circulating a letter. In addition, McCready was the only pirate denounced by name, safeguarding Moving Picture World from any accusation of maintaining a blacklist. Most of all, the principal information in this short news item is not the pirate's name. Instead, it conveyed that information was circulating within the legitimate industry (in this case in the form of a letter) even in the absence of a formal blacklist.

A second solution for fighting against piracy was to inform. Moving Picture World's editors, believing as we have seen that some owners of venues were poorly trained, dispensed warnings with a pedagogical aim. Readers were informed both about the risks of piracy ("all we will say at this time is to warn the exchanges against buying, at any price, spurious, smudgy slides which they must know are copies"53) and about the mediocre quality of the copied slides ("the quality of these slides is inferior both from a photographic standpoint as well as color" ${ }^{54}$ ).

A third solution was to rely on the law, by invoking copyright, a notice of which manufacturers should affix to their slides in order to register their property. What was mostly discussed in the journal, however, was the weak protection offered by copyright, as Simpson explained: "No other business is so subjected to the abuse of theft as ours. We have copyrighted our slides, but the copyright markings are removed, and our original works reproduced and sold at a reduced price in wholesale lots." 55 The copyright notice on the slides irritated the music publishers, in addition to viewers, who could take the notice for a defect. In fact, the notice had to be placed in the image; otherwise it would not be copied by the pirate and would be useless. Knowing how to protect one's slides from piracy was thus one quality of a legitimate operator: "Because the slide makers have not placed their copyright marks so they would show on the screen, is the reason that so many of the scamps who copy slides are still free to ply their nefarious trade." ${ }^{56}$ In contrast, the journal did not hesitate to ridicule some of the most primitive copiers, as seen in this final, edifying example, one so absurd that it seems exaggerated: "[Pirates] borrowed a genuine set of slides for 'Yesterday' ... and copied them. They even copied the title page slide which 
had the name of Scott \& Van Altena on it, and the counterfeited slides went out with Scott \& Van Altena's name upon them. A set of them found their way almost as soon as they were issued into Mr. Van Altena's hands." ${ }^{57}$

Piracy and the music publisher crisis, widely documented in the pages of Moving Picture World, appear to be the first tremors to shake up the illustratedsong industry in 1908. An analysis of the rhetorical techniques employed by the journal reveals that the publishers sought to unite the actors in this highly polarized sector: to distinguish them from one another, but also to isolate its legitimate representatives, whose ethical, legal, commercial, technical, and aesthetic practices were raised up as models.

\section{A FINANCIAL AND LEGAL CRISIS: EXCLUSIVE ILLUSTRATIONS}

A third crisis shines light on a decisive symbolic issue: that of exclusive illustrations. Less widespread than the others, this crisis nevertheless demonstrates that beyond the unity Moving Picture World sought to create there were tensions between slide manufacturers. Two personalities clashed: on the one hand Alfred Simpson, slide manufacturer and dealer, whose remarks were often reported in Moving Picture World; and on the other Henry B. Ingram, also a slide manufacturer and distributor. These two manufacturers were in addition regular buyers of advertisements in the paper on an almost weekly basis beginning in May 1908-a sign that they were viewed as legitimate by the journal and by their peers.

Their dispute became most explicit in the May 30, 1908, issue, in an open letter from Ingram to Simpson. But this letter was a response to Simpson's positions, which we should set out first. Simpson had asserted in various forums that he was the exclusive representative of certain music publishers with respect to the illustration of their songs. His advertisements mention this, as did several articles in Moving Picture World, which used expressions such as "under contract of sole illustration" and "sole illustration rights" (fig.1). The interest in holding an exclusive contract such as this was twofold: to limit competition, especially for hit songs; and to legally secure one's illustrations, in particular against pirated copies. This is seen in the text of his advertisements: "I have the sole illustration rights of these songs from the publishers of same and anyone making slides for any of the above songs are doing so without authority and should not be patronized." Ingram was not a pirate, but he was a competitor of Simpson's. His concise letter details why, under law, Simpson's contracts were worthless and why he would not hesitate to illustrate songs for which Simpson enjoyed so-called exclusivity. His reasoning was clever and very interesting from the perspective of media history: "You are aware, of course, that the copyright law gives to the music publisher only the exclusive publishing and selling rights to his publication and that he cannot prevent another publisher from publishing 


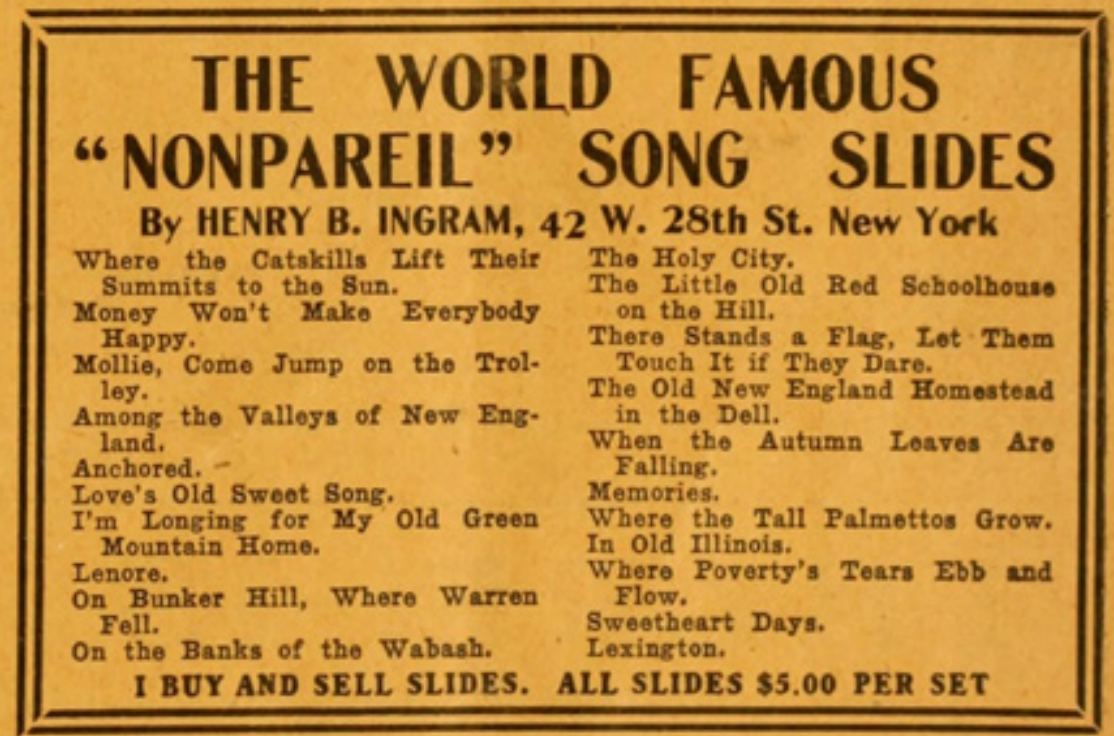

\section{Simpson's Celebrated Slides}

\section{THE FINEST SONG SLIDES MADE}

\section{\$5.00 PER SET}

Some unscrupulous houses are advertising unathorized slides for:- "Two dirty little hands," "Wont you be my baby boy," "Roses bring dreams of you," "“You splash me and I splash you," "Everybody loves me but the one I love." I have the sole illustration rights of these songs from the publishers of same and anyone making slides for any of the above songs are doing so without authority and should not be patronized.

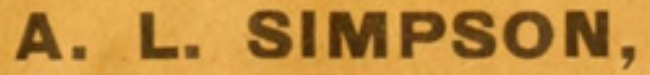

113 W. $132 \mathrm{~d}$ Street, - New York CitY

Fig. 1: Advertisements for Henry B. Ingram and Alfred L. Simpson on the same page. (Moving Picture World 3, no. 4 [July 25, 1908]: 75)

another song and using the same title." ${ }^{58}$ In sum, Ingram indicates that the music publisher's copyright protects only the musical score, meaning the new association of words and music, in written and published form. This, and only this, is what the publisher can grant the magic-lantern exhibitor. We must thus 


\section{Cimpson's Celebrated ong Slides The Finest Made. 55 per Set A. L. SIMPS0N, II3 W. 132 St., New York City}

Fig. 2: Advertisement for Simpson, as modified. (Moving Picture World 3, no. 5 [August 1, 1908]: 95)

understand that the song and the series of slides illustrating it were protected by copyright independently and not as a single work. In fact no audiovisual medium had yet fixed songs and their illustration together in a single recorded and synchronous work. Illustrated songs, moreover, did not reproduce the song's lyrics in their entirety, but rather only the chorus, and they could even sometimes be lacking a text slide.

If Ingram were to be accused of having illustrated a song under exclusive contract with Simpson, he would defend himself by claiming to have illustrated another song of the same title. In the absence of sound recordings of the songs, it would in fact be difficult for anyone to prove the contrary. This reasoning presented itself as a strict interpretation of the law. ${ }^{59}$ It is highly interesting because it rests on a close and fairly astonishing connection between legal protection for artworks and their technical base. It had its limitations because Ingram does not take the singer into account: one way or another, it had to be indicated to the singer which words had to be sung (those of the song under copyright by Simpson, or those of the hypothetical other song of the same title?). Nevertheless, Ingram appears to have acknowledged and even emphasized his bad faith with the ironic tone of his letter, which ends as follows: "I ran across a publisher this morning, Mr. Simpson, who actually believed that he could give you the exclusive right or monopoly of making pictures for his songs. It was my pleasure to disabuse him of the illusion. Yours truly, HENRY B. INGRAM." ${ }^{60}$ Did the dispute continue beyond the pages of the journal? That is difficult to say, for the question was practically no longer addressed there. An article devoted to Ingram the following week avoided the topic. ${ }^{61}$ And yet beginning August 1, 1908, Simpson's advertising in the paper was cut in half, with the claim "sole illustration rights" removed (fig. 2). Ingram's argument appears to have had an effect.

\section{CONCLUSION AND OUTLOOK}

The three crises I have discussed show that the illustrated-song industry was weakened in 1908. The free-slides crisis threw the illustrated-song industry into disorder at a time when sound recording technologies were being introduced. 
Piracy weakened slide manufacturers and distributors, who were obliged to establish a clear dichotomy between legitimate manufacturers and unfair competition. Finally, the crisis of exclusivity showed that even in the case of legitimate manufacturers, disputes set some actors in the market against each other. While they had to unite as a profession in order to be stronger, they nevertheless remained direct competitors, and within the boundaries of the legitimacy of their actions, they used any means they could to consolidate their activities. In describing these crises, I have endeavored to show, with hindsight, the rhetorical strategies at work in Moving Picture World in order to bring to light editorial biases, not only in the discourses of its editors but also in the way they presented and laid out external contributions. The journal used a number of strategies: outspoken disagreement and certain semantic fields, anonymous letters that created stereotypes according to one's duties, and open letters and first-person accounts that staged disputes. The range of rhetorical techniques allowed the journal to position itself as a place for discussion, assuming the role of moderator in the disputes while advocating for legitimate illustrated-song manufacturers and distributors.

Two paths now appear to open up to complete the conclusions of this initial study. The first consists in examining the positive discourses: not only to denounce bad practices, but to encourage good ones. My discussions of Moving Picture World reveal at least three ways of doing this. First, the paper assembled tutelary figures from the start in 1907, including DeWitt C. Wheeler, Alfred Simpson, and Charles K. Harris. The latter, for example, played a major role during the paper's first months. An author of songs and a publisher of music and slides, Harris wrote a long article for the first issue explaining how to "illustrate a song properly" to obtain "the most beautiful song pictures." ${ }^{2}$ The paper even had a long review of his book How to Write a Popular Song, a volume which was part manual and part autobiography. ${ }^{63}$ The review heaped praise on the book, illustrating the paper's editorial strategy of creating founding fathers of the illustrated song. ${ }^{64}$ In addition, the paper sought to be a pedagogical tool, by publishing in-depth articles on technical topics, particularly in a regular section entitled Lantern Slide Making, but also by publishing lists of reference works (Useful Books). Finally, by publishing reviews of series of slides, Moving Picture World helped define what made a good illustrated song, not only on a technical level but also in aesthetic terms.

The second path consists in broadening the field of research to other journals from the same period, such as Variety, the New York Clipper, and Views and Films Index (renamed The Film Index in $1908^{65}$ ). The "free music" crisis, for example, was the topic of an article by Alfred Simpson published May 16, 1908, in Views and Films Index, in which the author also raises the question of "exclusive 
rights to illustrate [a] song." ${ }^{66}$ Similarly, in January 1908, the paper mentioned the founding of an organization to bring professionals together around good practices and to battle piracy, using rhetoric similar to that of Moving Picture World: "This Association is not for the purpose of raising prices but for the protection against our common enemy, the pirate. The man who will copy another man's set of slides will steal" (emphasis added). ${ }^{67}$ Just like its rival, Views and Films Index offered, moreover, to be a place for discussing this topic. ${ }^{68}$ And yet a quick search suggests that in its pages piracy remained a rare topic-the term pirate returned in 1909, but with respect to films.

These indications, as brief as they may be, show that broadening the body of work studied would make it possible, through comparison, not only to offer more precise conclusions but also to distinguish more exactly the editorial policy of Moving Picture World from that of other trade or general interest publications. This would add further to our knowledge of the magic-lantern industry of the day, an industry whose bright colors, as demonstrated, were already fading by 1908 .

\section{Translated by Timothy Barnard}

\section{Notes}

The research on which the present text is based, as well as its translation, has received financial support from the International Partnership for Research into Cinema Techniques and Technologies (TECHNÈS). This text is a revised version of a research project carried out during the course Histoire du cinéma: Problèmes et méthodes taught by Louis Pelletier in the fall of 2017 in the Département d'histoire d'art et d'études cinématographiques at the Université de Montréal. The second section of the text was presented at the annual conference of the Film Studies Association of Canada (FSAC/ACÉC). The French version of this study received the 2018 Domitor Student Essay Award. The author extends his warm thanks to André Gaudreault and Martin Barnier and to Santiago Hidalgo, Louis Pelletier, Valentine Robert, and Jerry White.

1. See in particular Rick Altman, Silent Film Sounds (New York: Columbia University Press, 2004); and Jennifer Wild, “Sur le déclin d'un dispositif culturel: La chanson illustrée," 1895: Mille huit cent quatre-vingt quinze 47 (2005), posted December 1, 2008, http://1895.revues.org/324.

2. Richard Abel, "That Most American of Attractions, the Illustrated Song," in The Sounds of Early Cinema, ed. Richard Abel and Rick Altman (Bloomington: Indiana University Press, 2001), 147.

3. In particular I consulted archive.org, mediahistoryproject.org, search.projectarclight.org, and lantern.mediahist.org multiple times between October and December 2017. On the topic of digitization, see Eric Hoyt, “Lenses for Lantern: Data Mining, Visualization, and Excavating Film History's Neglected Sources," Film History 26, no. 2 (Summer 2014): 146-68.

4. On this topic see in particular André Gaudreault, Film and Attraction: From Kinematography to Cinema, trans. Timothy Barnard (2008; Urbana: University of Illinois Press, 2011).

5. The three volumes are available on archive.org and/or via the Media History Digital Library. Note that there are several classification problems in volume 3, which is missing issue no. 17 (October 24, 1908) and which contains the index for volume 2 rather than that for volume 3. 
6. “Slide Makers Organisation?," Moving Picture World 2, no. 2 (January 11, 1908): 25.

7. Richard Abel, "That Most American of Attractions," 14.

8. Rick Altman, Silent Film Sounds, color plates section (unpaginated, between pages 182 and 183).

9. Dan'l H. Palmer, "Music Publishers as Distributers [sic] of Lantern Slides," Moving Picture World 2, no. 21 (May 23, 1908): 454.

10. Note that women singers were more common than men. Nor was the rest of the industry closed to them, as attested for example by the role of Jane Addams, present in the pages of Moving Picture Journal from 1907. But it must be acknowledged that the industry was dominated by men and that the representation of women in Moving Picture World tended to reinforce this dominance. The excerpt quoted here does not mention the singers, who nevertheless were the topic of the following paragraph in this letter.

11. Buyers' Guide, Moving Picture World 1, no. 4 (March 30, 1907): 62.

12. "Publishers had to weigh the presumed efficacy of song slides to boost sheet music against the possibility that they were simply wasting resources that might be better spent on alternative modes of promotion." Matthew Mooney, "'All Join in the Chorus': Sheet Music, Vaudeville, and the Formation of American Cinema, 1904-1914” (PhD diss., University of California Irvine, 2006), 183.

13. Altman, Silent Film Sounds, 191.

14. For example, in the section Trade Notes of Moving Picture World, June 15, 1907, six of the fourteen articles on the opening of a venue explicitly mention a program with illustrated songs.

15. Mooney, "'All Join in the Chorus,"” 158.

16. "The Free Music Graft Is Ended," Moving Picture World 2, no. 17 (April 25, 1908): 366.

17. “The Free Music Graft Is Ended," 366.

18. "Always Trouble All the While," Moving Picture World 2, no. 18 (May 2, 1908): 397-99.

19. "Always Trouble All the While," 397-99.

20. News and Notes, Moving Picture World 2, no. 19 (May 9, 1908): 414.

21. Altman, Silent Film Sounds, 189: "The case of Keith's Providence Nickel Theatre offers an interesting perspective on the development of illustrated song technique during the nickelodeon era. Six months after opening, in October 1906, the Nickel hired Bob Alden as song illustrator. At first Alden accompanied himself on the piano while he sang. Within a few months the Nickel boasted a quartet singing such favorites as 'Like the Flower My Love Is Fading.' Nickel Theatre ads featured 'Bob Alden and the Nickel Quartette' in a larger typeface than the title of any film."

22. "Illicit Trading in Song Slides," Moving Picture World 2, no. 19 (May 2, 1908): 419.

23. "Illicit Trading in Song Slides," 419.

24. "Illicit Trading in Song Slides," 419.

25. Among the Slide Makers, Moving Picture World 2, no. 25 (June 20, 1908): 529.

26. "Not a Hit Song on the Market," Moving Picture World 3, no. 1 (July 4, 1908): 6.

27. "Not a Hit Song on the Market," 6.

28. "Not a Hit Song on the Market," 6.

29. Wild, "Sur le déclin d'un dispositif culturel," 8. 
30. The three quotations are from "Slide Makers Organizing," Moving Picture World 2, no. 1 (January 4, 1908): 6-7.

31. The two quotations are from: "De Witt C. Wheeler \& Co. and the Slide Makers' Protective Association," Moving Picture World 13, no. 1 (July 4, 1908), 9.

32. "Slide Makers Organizing," 6; and "De Witt C. Wheeler \& Co.," 9.

33. As can be seen, anonymous letters appear regularly in Moving Picture World. We might think, without naïveté, that this format enabled the journal's editors to join in the discussion in a polemical manner under the cover of anonymity. At the very least, the technique was used for its rhetorical effect.

34. "Moving Picture Shows Using Copied Lantern Slides," Moving Picture World 2, no. 24 (June 13, 1908): 514.

35. "Moving Picture Shows Using Copied Lantern Slides," 514.

36. “De Witt C. Wheeler \& Co.," 9.

37. Sources for quotations: "injuring," Among the Slide Makers, October 30, 1908, 337; "daubers," "Slide Makers Organizing," 7; "bathroom photographers" and "junk," "De Witt C. Wheeler \& Co," 9; "slides painted like a house painter does his work," "The Tremendous Demand for Song Slides," Moving Picture World 1, no. 30 (September 28, 1907): 467-68, quotation on 468; "punk," "Moving Picture Shows Using Copied Lantern Slides," 514; and "trash," Palmer, “Music Publishers as Distributers [sic] of Lantern Slides," 454.

38. Among the Slide Makers, Moving Picture World 3, no. 18 (October 30, 1908): 337.

39. Among the Slide Makers, October 30, 1908, 337.

40. The term posing is sometimes used as a synonym for illustrate a song, especially by Charles K. Harris: "They never go to the trouble or expense of posing a song; most all of them, in fact, know little about the art of photography"; and "At the present time I have a staff of photographers in Florida, where they are now posing my latest Southern pastoral song." See Charles K. Harris, "Illustrating Song Slides," Moving Picture World 1, no. 1 (March 9, 1907): 6. Another example: "In addition to this, there are many firms who do no posing, but depend entirely upon securing one of the first copy [sic] of new song slides, from which they make negatives." "Anent Slide Copying," Moving Picture World 3, no. 7 (August 15, 1908): 124.

41. "Slide Makers Organizing," 6-7, quoting Alfred Simpson.

42. "De Witt C. Wheeler \& Co.," 9.

43. "Slide Makers Organizing," 6-7.

44. "Picked Up among the Slide Makers," Moving Picture World 2, no.19 (May 9, 1908): 414.

45. "Faking Song Pictures," Moving Picture World 2, no. 22 (May 30, 1908): 474.

46. "Anent Slide Copying," 124.

47. "Moving Picture Shows Using Copied Lantern Slides," 514.

48. Among the Slide Makers, October 30, 1908, 337; and "Making Slides for Picture Songs," Moving Picture World 1, no. 39 (November 30, 1907): 633.

49. This in any event is what is said in the anonymous letter of the singer "who pays for his slides": "it was practically a black list (which, by the way, is forbidden by law, a severe penalty being attached to the issuing of a black list in this State)." "Illicit Trading in Song Slides," 419.

50. "Faking Song Pictures," 474.

51. “De Witt C. Wheeler \& Co.," 9. 
52. Trade Notes, Moving Picture World 3, no. 2 (July 11, 1908): 29.

53. “De Witt C. Wheeler \& Co.," 9.

54. "Anent Slide Copying," 124.

55. "Slide Makers Organizing," 6-7.

56. Editorial Notes and Comments, Moving Picture World 2, no. 20 (May 16, 1908): 436.

57. "The Business of Copying Other People's Slides Unprofitable," Moving Picture World 2, no.17 (April 25, 1908): 367.

58. "An Open Letter," Moving Picture World 2, no. 22 (May 30, 1908): 478.

59. "An Open Letter," 478. "Will you kindly inform me where you or they find any law that allows them to give you this right or protects you in it after they have given you that right?" I have not been able to consult the laws in force at that time, but these texts would undoubtedly make it possible to understand Ingram's hermeneutics better.

60. "An Open Letter," 478.

61. "Henry B. Ingram, the popular lantern slide maker of 42 West Twenty-eight street, dropped in the other day with a list of new songs which he has illustrated and which will be seen in his advertisement. He said that he was in full sympathy with the articles recently published in this paper, warning the trade against the slide copyists, and assured us that while his business had felt the effect of the slide pirates, he retained a steady and increasing trade from those concerns which valued their reputation for handling only original slides of high quality." Trade Notes, Moving Picture World 2, no. 23 (June 6, 1908): 492.

62. Harris, "Illustrating Song Slides," 7.

63. Editor's Table, Moving Picture World 1, no. 5 (April 6, 1907): 73.

64. Editor's Table, 73. "The biography is very interesting reading, as it introduces us to a phase of Mr. Harris's life showing how he made his successes, and is a stimulus to others of like bent, although it will be difficult matter to find another who can spring to fame like the author."

65. Some of these titles are already available, for the period 1907-8, at archive.org and via the Media History Digital Library and its search engine Lantern. Views and Films Index became The Film Index with the publication of issue 127 on September 26, 1908. Similarly, The Moving Picture World and View Photographer was renamed The Moving Picture World on May 11, 1907 (vol. 1, no. 10). This marked the decline of the use of the term view to describe both slides and films in favor of film, motion pictures, or moving pictures, which gave us movies. In renaming themselves, however, the two publications did away in their title with any mention of lantern slides, thereby already revealing the symbolic decline of the practice.

66. Alfred Simpson, "News for Slide Users," Views and Film Index 108 (May 16, 1908): 5-6. "It may interest the profession to know that all of the good music publishers positively assert that they will furnish no more professional copies to anyone for any purpose whatsoever-except to legitimate performers who are doing their music purely as an advertisement for them."

67. Views and Films Index 89 (January 4, 1908): 14-15. Page 14 is missing in the currently available digitized version, preventing us from knowing the identity of the column's author, who is an author and publisher of songs and slides. Mention of the song "Yesterday" suggests that it may have been Charles. K. Harris.

68. Views and Films Index 89 (January 4, 1908): 14-15. "The VIEWS AND FILMS INDEX invites discussion of the question, and places its offices at the disposition of any slide maker who may choose to give his opinion or make any suggestion." 
Robin Cauche began his career as a video editor and worked several years for a music channel. Also a French teacher, he is now a PhD candidate in cinema and audiovisual studies. His research on the history and aesthetics of illustrated songs is supervised jointly by Martin Barnier (Université Lumière Lyon 2) and André Gaudreault (Université de Montréal). 
Copyright of Film History is the property of Indiana University Press and its content may not be copied or emailed to multiple sites or posted to a listserv without the copyright holder's express written permission. However, users may print, download, or email articles for individual use. 